\title{
Geophysical changes detection by remote sensing in Alaminos River Pangasinan, Philippines
}

\author{
Annie Melinda Paz-Alberto ${ }^{1}$, Edmark P. Bulaong1, Ranilo B. Lao ${ }^{1}$, Eleazar V. Raneses ${ }^{1}$, Bennidict P. Pueyo ${ }^{1}$ \\ 1 Institute for Climate Change and Environmental Management, Central Luzon State University, Science City of Muñoz 3120 , Nueva Ecija, \\ Philippines \\ * Corresponding Author: Dr. Annie Melinda Paz-Alberto, Central Luzon State University, Science City of Muñoz 3120, Nueva Ecija, Philippines; \\ melindapaz@gmail.com
}

\begin{abstract}
Geophysical changes of the river outlets, riverbanks and coastlines in Alaminos, Pangasinan were measured using Google Earth from 2009 to 2014. On the other hand, actual measurements were gathered using South Total Station (NTS-362R6L) in 2015. The insights of the residents regarding feature changes of the river were obtained through one on one interview. Root Mean Square Errors (RMSE) were computed for measurement and horizontal positional accuracy of Google Earth. To perceive the effects of sea levels, historical data (2004-2015) from Bolinao, Philippines Tide Chart at online tides and currents predictions were also analyzed. Alaminos river outlets decreased in width size due to natural factor and human activities. Alaminos riverbank increased in width size which could be possibly due to natural calamities and weak bank resistance brought about by the frequent flooding caused by heavy rains and the emergency released of water from San Roque Dam. Generally the north and south coasts of Alaminos River increased and expanded. Rise in sea level is also a probable cause of changes wherein heights of low tides in Pangasinan Gulf is increasing overtime. The computed RMSE was low which indicate positional accuracy and measurement of Google Earth in the study area.
\end{abstract}

Keywords: Remote Sensing; Accretion; Erosion; Fish pens/cages

\section{Introduction}

The Alaminos River and coastlines is highly utilized for livelihood and coastal tourism. The gulf contains one of the oldest national parks in the country, the "Hundred Islands" of the municipality of Alaminos. Low lying areas in Pangasinan are always prone to flooding during typhoons due to its geographic location. Local topography, including lengthy river and ocean coastlines, dense urban development patterns, the capacity of our aging sewer system and increasingly extreme weather are some of the biggest causes of flooding. Floods can have devastating consequences and have effects on the economy, people and natural resources. In this study, the detection of changes in coastlines, river outlet and riverbanks of Alaminos River in Pangasinan using remote sensing from the Google Earth was used.

\section{Objectives of the study}

This study aimed to determine the geophysical changes of the river outlet, upstream and coastline in Alaminos, Pangasinan. The study specifically aimed to:

a. Detect and analyze the geophysical changes in the river outlet, upstream and coastline through satellite imagery and;

b. Determine the causes of geophysical changes in the river outlet, upstream and coastline

\section{Materials and methods}

Copyright (C) 2018 Annie Melinda Paz-Alberto et al.

doi: $10.18063 /$ som.v3i2.688

This is an open-access article distributed under the terms of the Creative Commons Attribution Unported License

(http://creativecommons.org/licenses/by-nc/4.0/), which permits unrestricted use, distribution, and reproduction in any medium, provided the original work is properly cited. 


\subsection{Google Earth historical imagery}

Satellite images of the Google Earth from years 2004 to 2014 in Alaminos River in Pangasinan, were used in the analysis to identify changes. Clear images of the river outlet, coastlines and upstream of the different rivers of the selected watersheds were analyzed quantitatively. Moreover, the actual data of the river outlet, coastline and river bank upstream of the said rivers were gathered in September 2015 and November 2015. The methodology used in gathering data in different study sites such as river outlet, coastline and river bank upstream of the watersheds are as follows:

\subsubsection{River outlet}

The distances of the river outlet for years 2009 to 2013 were measured. Only clear images on the historical views of the Google Earth were analyzed. Gathered data from Alaminos River were compared from 2009 to 2013, where 2009 is the basis of comparison.

\subsubsection{Riverbank}

The width of the riverbank was measured every $500 \mathrm{~m}$ from the outlet of the river to upstream. Data were gathered using clear historical imagery of the Google Earth from 2009 to 2013.

\subsubsection{Coastline}

Data were gathered from both north and south coastlines of the river. The coastlines in the year 2009 were the baseline for measurement for the Alaminos River. Coastlines were measured every 500 meters from the coastline near the outlet of the river up to the coastline of the nearby river. Images were analyzed if the changes were moving seaward or landward.

\subsubsection{Field validation}

Coordinates of every sampling points of the latest Google Earth Satellite images were recorded for field validation. The actual distance of the river outlet was measured on November 2015 by the LiDAR1 researchers using South Total Station (NTS-362R6L).

\subsubsection{Root mean square error (RMSE) computation}

RMSE measures how much error there is between two datasets, usually compares a predicted value and an observed value. In this study, coordinates gathered during the field validation were plotted in Google Earth and measured to compare with the validated measurement. RMSE takes the difference for each Google Earth Measurements (predicted value) and Field Validated Measurements (observed value) and the results squared to have a positive value. Then divide the sum of all values by the number of observations, which is then be square-rooted to have the Root Mean Square Error. Below is the formula used for RMSE (1):

$$
R M S E=\sqrt{\frac{1}{N} \sum_{p=1}^{N}\left(x_{p}-x_{o}\right)^{2}}
$$

Where $\mathrm{X}_{\mathrm{p}}=$ predicted value

$\mathrm{X}_{\mathrm{o}}=$ observed value

$\mathrm{N}=$ number of sample

\subsubsection{Community survey on coastline and river changes of Alaminos}

A questionnaire regarding river and coastal changes was constructed specifically to determine the natural occurrences and the natural features of the area. Twelve points were strategically selected along the river and the coastlines to form focused groups that provided the most useful data. Focused groups were formed by selecting residents residing at least a decade in the area for them to describe the historical changes and natural occurrences in the area. The community survey was conducted on September 15-17, 2015 in Alaminos River in Pangasinan.

\subsubsection{Measuring sea level rise}

The historical record from tide gauges of Bolinao, Philippines Tide Chart at online tides and currents predictions ${ }^{[8]}$ (Online Tides WorldView) for the years 2004 to 2015 were gathered to perceive the changes of the sea level. Records of the low tide and high tides per day were determined. Gathered data was compared and analyzed and see the flow of tide within a decade data. 


\section{Results and discussion}

\subsection{Alaminos watershed}

Alaminos River is located in Province of Pangasinan, Ilocos, Philippines. The estimate terrain elevation above sea level is 17 meters. Variant forms of spelling for Alaminos River or in other languages: Barcadero River, Paitan River, Masedem, Alaminos, Amandiego River, Amediago River, Amendiago River, Alaminos River, Alaminos, Alaminos River, Amandiego River, Amediago River, Amendiago River, Barcadero River, Masedem, Paitan River. Alaminos River Watershed has an area of 22,227.76 hectares, covering Alaminos City, Sual, Mabini, and small portions of Bani and Labrador, Pangasinan ${ }^{[1]}$ (DENR 2013). It is situated at Western Pangasinan between $16^{\circ} 00^{\prime} 10.31$ " to $16^{\circ} 14^{\prime} 51.4^{\prime \prime}$ North Latitude and $119^{\circ} 55^{\prime} 9.21^{\prime \prime}$ to $120^{\circ} 05^{\prime} 18.09^{\prime \prime}$ East Longitude. It is bounded in the north by the Lingayen Gulf, in the east by Labrador, in the South by Dasol, and in the west by Bani ${ }^{[2]}$ (Alaminos River Watershed Characterization).

\subsection{Alaminos river outlet}

The Alaminos River has two main outlets labeled as "Outlet A" and "Outlet B". Outlet A has minimal changes, from $193 \mathrm{~m}$ in 2009 it narrowed down to $189 \mathrm{~m}$ in 2014 and then widens to $191 \mathrm{~m}$ in 2015 as from the data gathered in the field validation. Outlet B remained unchanged at $299 \mathrm{~m}$ in 2009 to 2014 but did changed a little in 2015 with the width of $300 \mathrm{~m}$ (Figure 1). These minimal changes and maintenance of the land area near the river mouths might be the result of manmade infrastructures like salt beds and fish pens made of solid rocks and soil further hardened with vegetation (Figures $2 \& 3$ ).
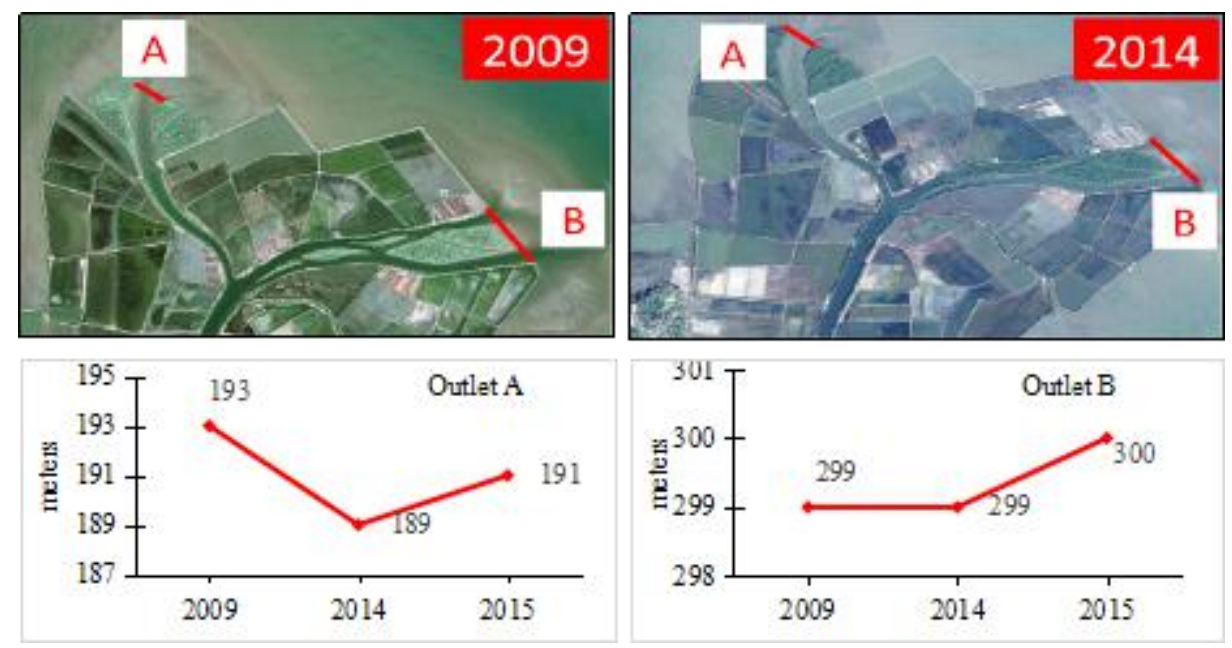

Figure 1. Alaminosriver outlets A and B and their changes over the years

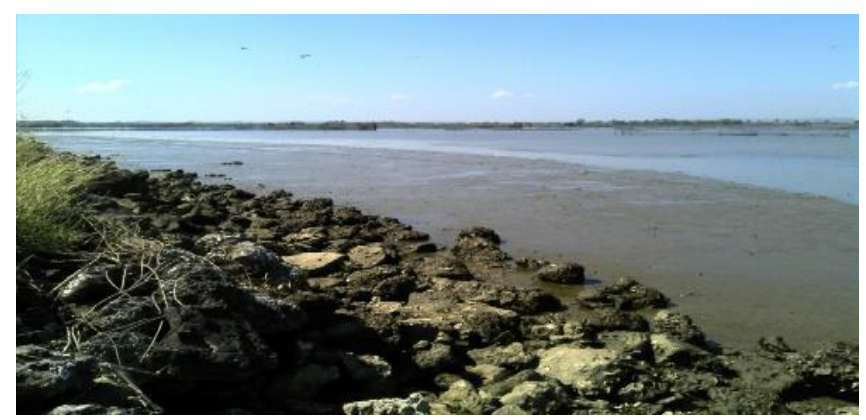

Figure 2. Rocks with vegetation near the River mouth (2015) 


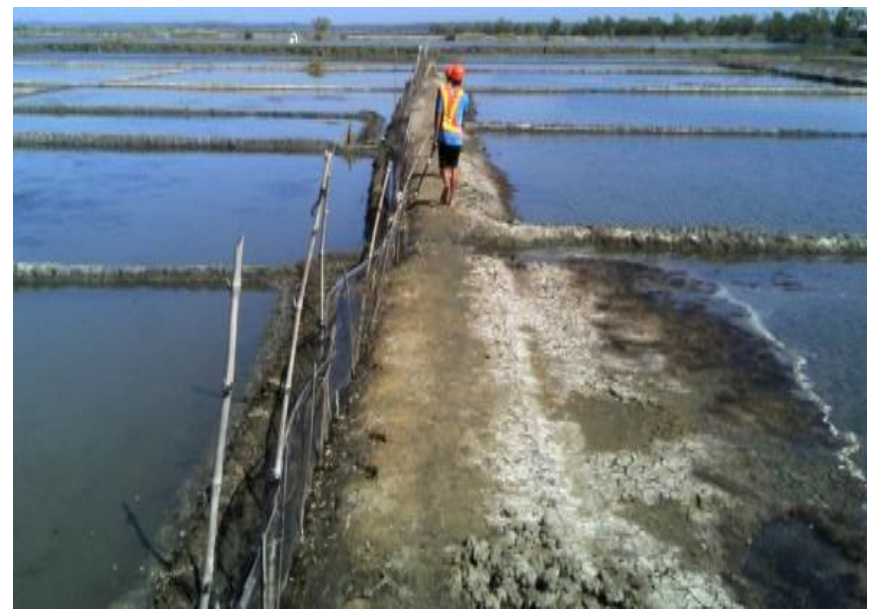

Figure 3. Salt beds near the River mouth (2015)

\subsection{North coastlines of Alaminos River}

Figure 4 shows the changes occurred at the north coastlines of Alaminos River from 2009 to 2015 with the latest satellite image captured in 2014. Majority of the changes were dominated by accretion. Vegetation and manmade developments specifically for livelihood purposes have caused the changes in this area.

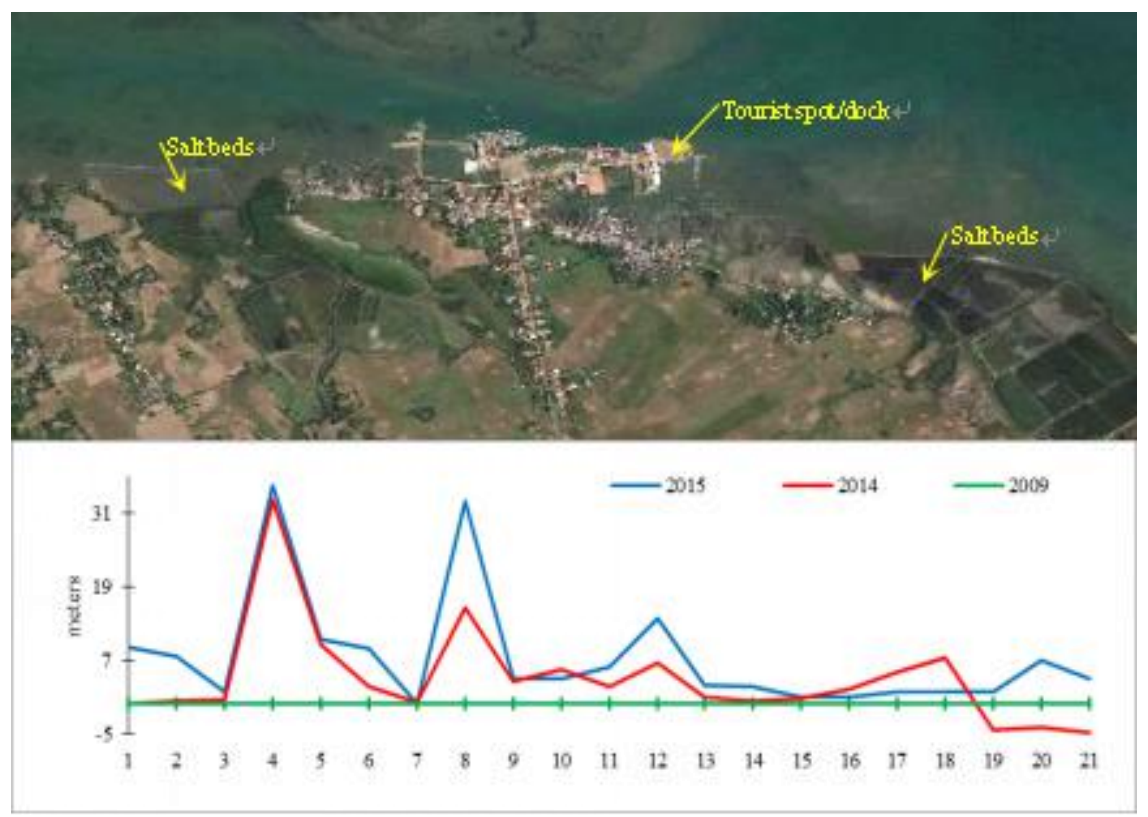

Figure 4. North coastlines of Alaminos River

The northcoastlines of Alaminos is highly utilized for tourism. Although salt beds are can be found throughout this area, tourism is the main source of living in this part of the coast specifically in Lucap in which the famous "Hundred Islands" is located.

\subsection{South coastlines of Alaminos River}

Figure 5 shows the alteration in the south coastlines of Alaminos River from 2009 to 2015 also with a satellite image taken in 2014. Overall, the data indicates that the land in this area has expanded from 2009 throughout 2015. 


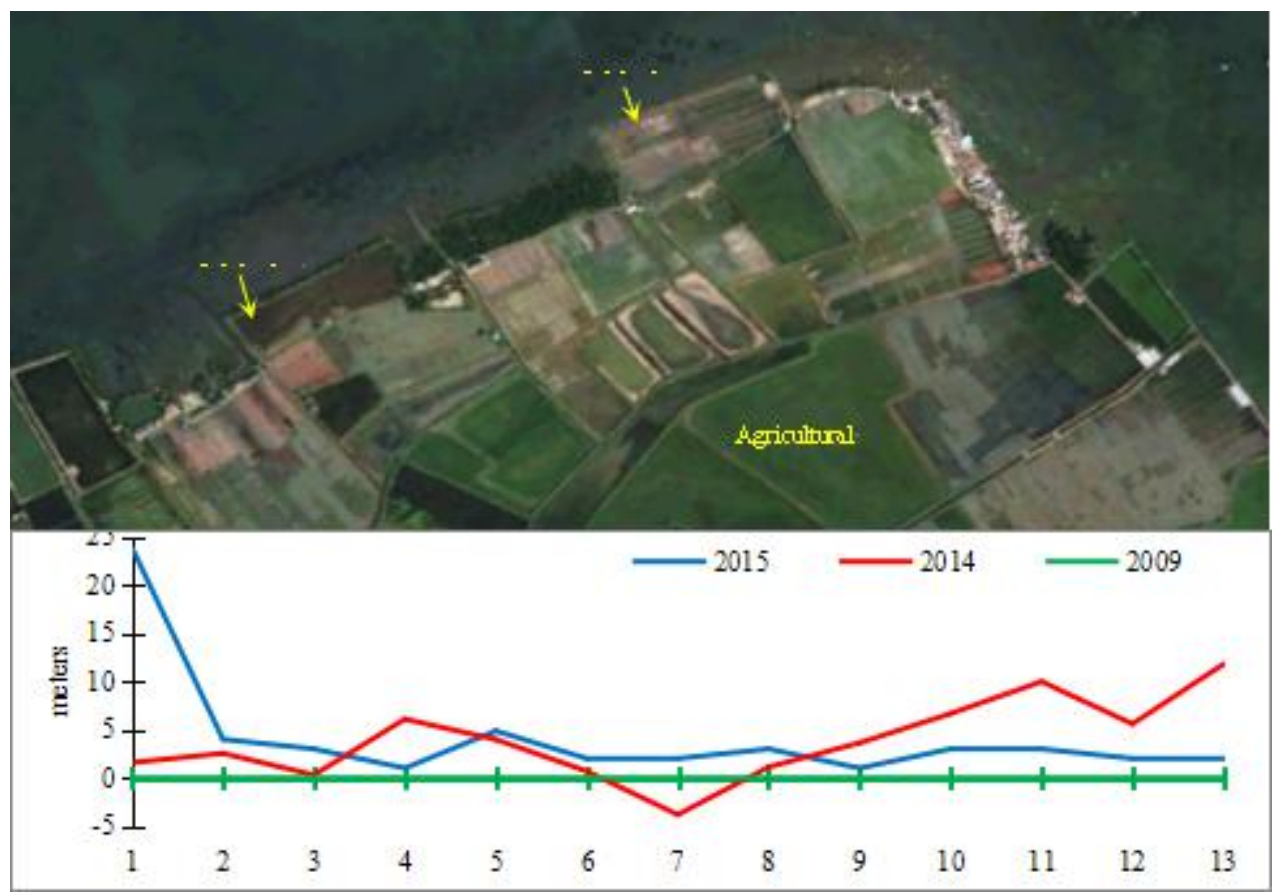

Figure 5. South coastlines of Alaminos River

The south coastlines of Alaminos River consist mainly of salt beds followed by fish pens, agricultural lands and very few communities. Salt is one of the primary sources of livelihood in the province of Pangasinan. According to the website ${ }^{[3]}$ All about Alaminos City, etymologically, the term Pangasinan means the "place where salt is made", owing to the rich and fine salt beds which were the prime source of livelihood for the province's coastal towns.

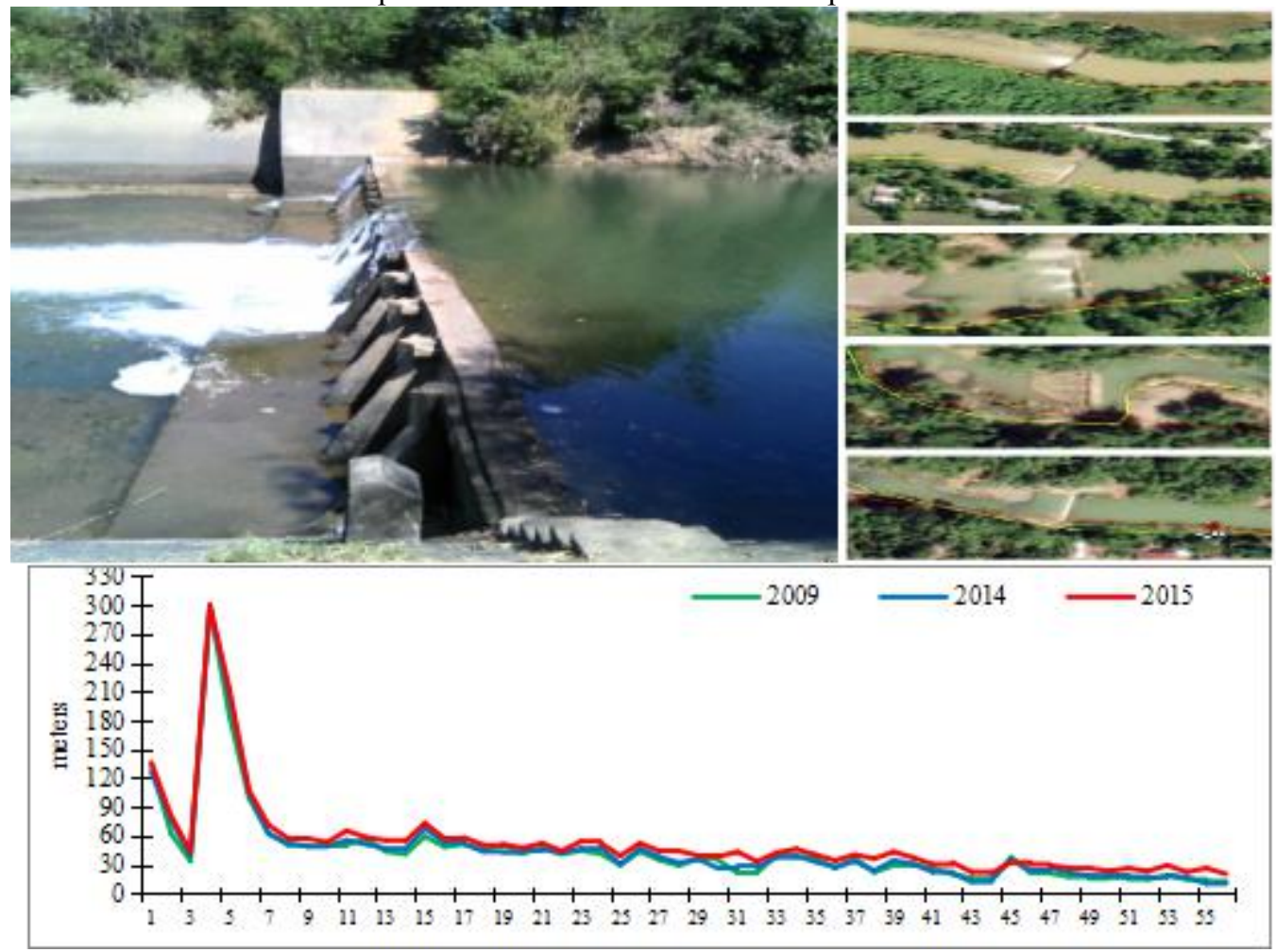

Figure 6. Alaminos riverbank

Dams were also constructed (as shown in Figure 6) at the upstream to control the water level that is being used for agricultural crop production purposes in which rice is the most dominant crop as recorded by the ${ }^{[4]}$ Comprehensive Land Use Plan 1999-2004 of the Local Government Unit of Alaminos City. 


\subsection{Root mean square error}

Minimal Errors between the measured data in Google Earth and the actual measurements during the field validation are found in the result of RMSE computation in Alaminos River Watershed coastlines, river bank and outlet. The north coast and south coasts of the river have the same average of $0.31 \mathrm{~m}$ discrepancy while the river bank has an average difference of $0.33 \mathrm{~m}$. On the other hand, the river mouth has shown a zero percent discrepancy between the Google Earth measurements and the actual measurement. Google Earth uses terrain data from the two main sources: the Shuttle Radar Topography Mission (SRTM) and the ASTER satellite in which both are being employed by NASA $^{[5]}$ (Friess 2011).

\subsection{Social aspect}

Information on major features of the Alaminos River, coast and natural disasters were gathered last November 26-27, 2015 through one on one interview with the residents near the coast and river of Alaminos.

\subsection{Alaminos River major features}

From the information gathered from the residents which was presented in Table 1, it can be inferred that several phenomenon and changes took place in Alaminos River. According to the residents, the Alaminos River widens over the years, and is becoming muddy whenever there is heavy rain especially if the rain is brought by a typhoon. The residents also observed that the water in the river mouth and salt beds gradually becomes more obscured because of aquatic waste deposits. The normal height of waves in the coasts is only less than a meter however rising up to two meters during typhoon season. Several salt beds were also observed near the river mouth and coastal areas through ocular inspection. Local water district is also available in the area which is used only for bathing and laundry purposes because the residents prefer to have deep well water to drink.

\begin{tabular}{|c|c|c|}
\hline Changes Observed & \multicolumn{2}{|c|}{$\%$ of respondents who observed such changes } \\
\hline Widening of river & $100 \%$ & $\begin{array}{l}\text { Observed by the residents in the river and in the } \\
\text { river mouth }\end{array}$ \\
\hline Most areas became muddy & $100 \%$ & $\begin{array}{l}\text { Observed in the river and river mouth and } \\
\text { especially during typhoon }\end{array}$ \\
\hline High Turbidity & $100 \%$ & River mouth/salt beds, due to aquatic wastes \\
\hline Flat and Narrow coast & $100 \%$ & $\begin{array}{l}\text { Coast are not visible in the area due to numerous } \\
\text { settlements and fish pens in the area }\end{array}$ \\
\hline Wave height less than 1 meter & $100 \%$ & Coastal area \\
\hline $\begin{array}{l}\text { Significant wave height of up to- } 2 \text { meters } \\
\text { during storm }\end{array}$ & $100 \%$ & Coastal area \\
\hline Abundance of Salt beds & $20 \%$ & River mouth and Coastal areas \\
\hline Local Water District & $\begin{array}{l}\text { For laundry } \\
\text { and bathing }\end{array}$ & River and Coastal Areas \\
\hline DeepwellJetMatic/handpump & Drinks sources & River and Coastal Areas \\
\hline
\end{tabular}

Table 1. Features and changes observed in Alaminos River in Pangasinan

\subsection{Coastlines of Alaminos River major features}

Sandy and rocky coasts were observed in the area but mostly sandy, dead corals emulsified with mud and soil were used to fortify farm dikes for fish pens and salt beds. Numerous settlements and fish pens were observed in the area. A coast was not visible in plain sight, but during high tide, the residents described the waves as calm and mild most of the time. Waves during storms sometimes reach 3 meters but residents observed that winds did much more effect/damage than waves most of the time per average year. A port/pier was usually found on the end roads or the port-to-market road, islands or what as popularly known as the Hundred Islands are the natural features present near the coastal areas. 


\subsection{Natural disasters in Alaminos River and coastal areas}

Majority of the residents near the Alaminos River experienced the effect of several typhoons as stated in Table 2. The typhoons also brought flooding in the area especially in the river mouth. Other natural disasters like earthquakes were felt in some areas in the past years. Also, according to the residents, incidents of fish kill occur in the river especially during summer time and or during the event of El Niño. Typhoons Emon, Kosme, Ondoy and Lando were the typhoons which greatly affected the area as described by the residents. Strong winds usually tore apart their houses which were situated in open areas like in the salt bed areas.

\begin{tabular}{|l|l|l|}
\hline Natural Disaster & \multicolumn{2}{|l|}{$\%$ of respondents who had frequently experienced such natural disasters in specific parts } \\
\hline Typhoon & $61 \%$ & Strong winds and cause flooding in lower areas and in the river mouth \\
\hline Flood & $35 \%$ & Up to 2 feet flood by typhoon and high tide \\
\hline Earthquake & $3 \%$ & Felt in some parts \\
\hline Poisoning & $1 \%$ & During summer or el Niño, poisoning of fish pens/cages \\
\hline
\end{tabular}

Table 2. Natural disasters in Alaminos River and its coastal areas in Pangasinan

\subsection{Measuring sea level rise in Pangasinan}

Sea level rises can considerably influence human populations in coastal and island regions and natural environments like lost habitat for fish, birds, and plants.

Scientific research indicates sea levels worldwide have been rising at a rate of 0.14 inches ( 3.5 millimeters) per year since the early $1990 \mathrm{~s}^{[6]}$ (Critical Issues Regarding Sea Level Rise). The rate of rise is 0.12 inches per year since 1992 using the satellite altimetry method ${ }^{[7]}$ (Rising of Sea Level Facts).

The graph shown in Figure 7 is a decade collective data from Bolinao Philippines tide chart at ${ }^{[8]}$ Online Tides WorldView.It provides tide predictions for over 7000 places around the world. Bolinao tide table-peak measurement predictions per year which represent the tide level measurements in the coastal areas of Pangasinan depicted that, average level of low tides in Pangasinan Gulf is increasing overtime. The average low tide in2004 (-0.098 m) and the average low tide in 2015(-0.045) had an average difference of 0.053 meter in terms of water level. The water level in the recent years $(2013,2014 \& 2015)$ is nearer to land area than in the year 2004. However, the level of high tides in the year 2010 to 2015 is lower than in the year 2004 to 2009. As the level of low tides increases, the level of high tides decreases.

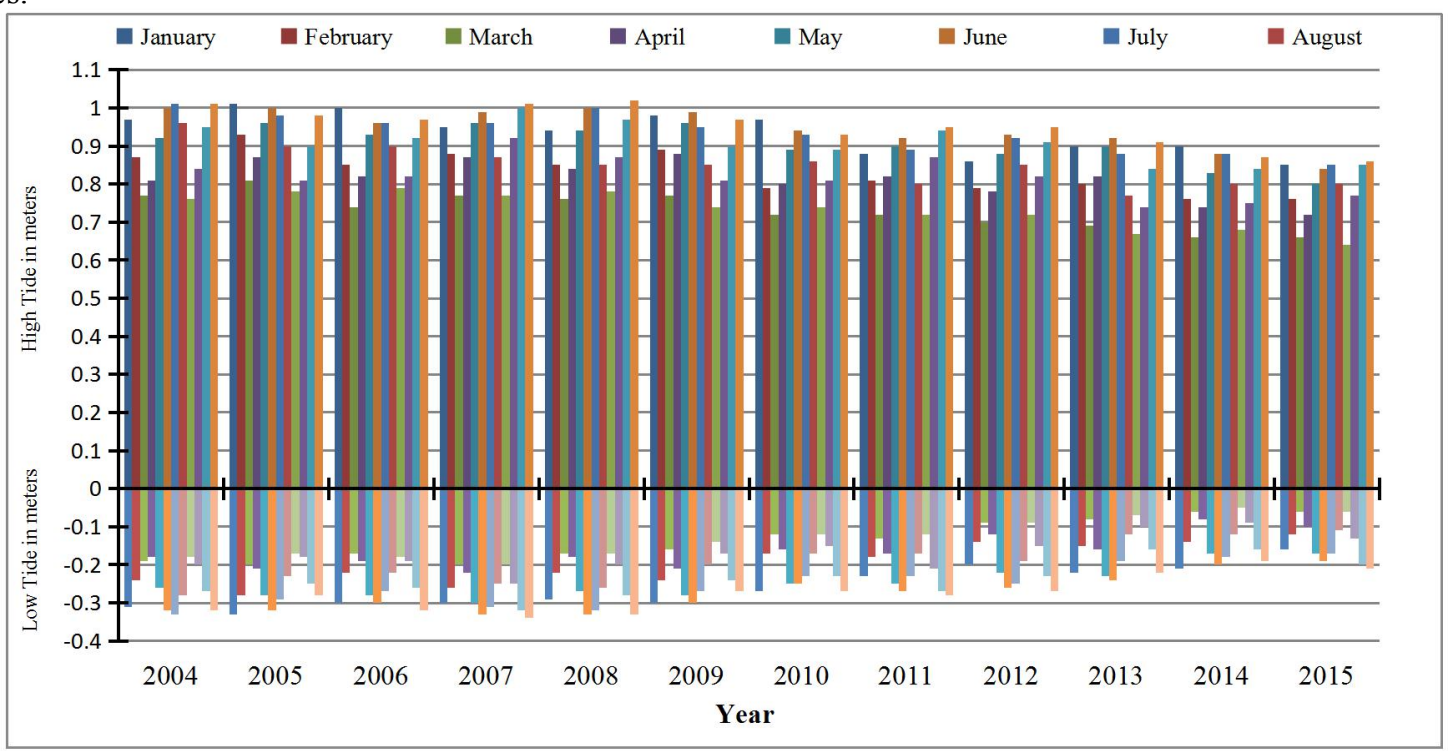

Figure 7. Tide table-peak measurement per year at Bolinao, Pangasinan

The trend, linked to global warming, puts thousands of coastal cities, even whole islands at risk of being claimed by the ocean.Over the past century, the burning of fossil fuels and other human and natural activities has 
released enormous amounts of heat-trapping gases into the atmosphere. These emissions have caused the Earth's surface temperature to rise, and the oceans absorb about 80 percent of this additional heat. The rise in sea levels is linked to three primary factors, all induced by this ongoing global climate change such as thermal expansion, melting of glaciers and polar ice caps, and ice loss from Greenland and West Antarctica ${ }^{[9]}$ (Bates, B.C., Z.W. Kundzewicz, S. Wu and J.P. Palutikof, Eds., 2008). Sea-level rise may continue to accelerate thus further monitoring can provide exact measurement ${ }^{[10]}$ (Nicholls, et al., 2010).

\section{Conclusion}

Alaminos river outlets showed different changes caused by artificial and natural means. The decreased and increased of the river outlets maybe due to the saltbeds and fish pens occasionally built and relocated in the area. Some saltbeds and fish pens were made from hardened dead corals found abundantly in the area making the structures hard and durable. Man made structures were also found in the coast having it highly utilized for livelihood and tourism which then results to accretion and erosion overtime. Generally the North Coast and South Coast of Alaminos River increased and expanded from the year 2004 to 2015. Coastlines were used mostly for beach front resorts wherein some artificial development and land use takes place. According to the interview, average beach waves were observed and strong winds and waves brought by natural occurences susch as typhoons were weaken by the islands of brgy Lucap situated on the otherside, front of the coastline. Agricultural development were observed near the river bank which loosens the soil being cultivated eventually washing it to lower areas and in the coastlines which may result to land expansion or erosion. The Alaminos river were also used for irrigation purposes wherin small dams were built to supply water in different farm lands in the area.

\section{Acknowledgment}

The authors would like to extend their sincere gratitude to the Department of Science and Technology (DOST) for the financial support and to the Philippine Council for Industry, Energy Emerging Technology Research and Development (PCIEERD) for monitoring and providing assistance in the implementation of the project.

\section{Author Contributions}

\begin{tabular}{|l|l|}
\hline Authors: & Responsibility \\
\hline Dr. Annie Melinda Paz-Alberto & $\begin{array}{l}\text { The main author of this study; Supervised and implemented protocols and } \\
\text { workflow of the study; Responsible in editing and finalizing the paper }\end{array}$ \\
\hline Mr. Edmark P.Bulaong & $\begin{array}{l}\text { Co-author; Assisted in writing and finalizing the paper; Obtained primary } \\
\text { data and secondary data }\end{array}$ \\
\hline Engr. Eleazar V. Raneses & $\begin{array}{l}\text { Co-author; Conducted validation study and field measurements and } \\
\text { analyzed the data ; }\end{array}$ \\
\hline Engr. Bennidict P. Pueyo & $\begin{array}{l}\text { Co-author; Gathered socio-economic data and wrote the socio-economic } \\
\text { part of the paper }\end{array}$ \\
\hline Mr. Ranilo B. Lao
\end{tabular}

\section{Conflict of Interest}

No conflict of interest was reported by the authors.

\section{References}

1. Department of Environment and Natural Resources (DENR). 2013. Alaminos River wathershed characterization report.

2. Alaminos River watershed characterization, Pangasinan, Philippines. Available Online: http://ph.geoview.info/alaminos_river, 1731684 Accessed on Sept. 7, 2015.

3. All about Alaminos City, Pangasinan, Philippines. Available Online: http://www.visitmyphilippines.com/index.php? title=pangasinan\&amp;func=all\&amp;pid=419\&amp;tbl=0. Accessed on Dec. 17, 2015.

4. Comprehensive land use plan 1999-2004 of the local government unit of Alaminos city. Available Online: 
http://alaminoscity.gov.ph/forms/Comprehensive\%20Land\%20Use\%20Plan/CLUP_1999-2004/pdf/Chapter \%20II I/IIIA1.pdf. Accessed on Nov. 16, 2015.

5. Friess, Daniel A. 2013. Using Google Earth for environmental research. Retrieved at http://www.themangrovelab.com/Google\%20Earth\%20Guide-1.pdf. Retrieved on April 13, 2016.

6. Critical issues regarding sea level rise. Available Online: http://ocean.nationalgeographic.com/ocean/critical-issues-sea-level-rise/. Accessed on November 16, 2015.

7. Rising of sea level facts. Available Online: http://oceanservice.noaa.gov/facts/sealevel.html Accessed on November 16, 2015.

8. Online tides worldview. Available Online: http://tides.mobilegeographics.com/locations/. Accessed on January 18, 2016.

9. Bates BC, ZW Kundzewicz, S Wu, et al. 2008. Climate change and water. Technical Paper of the Intergovernmental Panel on Climate Change, IPCC Secretariat, Geneva, $210 \mathrm{pp}$.

10. Nicholls RJ, Cazenave A. Sea-Level rise and its impact on coastal zones 2010; 328(5985): 1517-1520 